\author{
(1) Pınar İncel Uysal, \\ (1) Yıldız Hayran, \\ (1) Neslihan \\ Akdoğan, \\ (1) Ayşe Öktem, \\ (1) Ahmet Atilan, \\ (1) Güneş Gür Aksoy, \\ (1) Başak Yalçın
}

\section{Effect of Omalizumab Therapy on Coagulation Parameters and Total Immunoglobulin E Levels in Patients with Chronic Idiopathic Urticaria and Bullous Pemphigoid}

\author{
Kronik Idiyopatik Ürtiker ve Büllöz Pemfigoidli \\ Hastalarda Omalizumab Tedavisinin \\ Koagülasyon Parametrelerine ve Total \\ İmmünoglobulin E Düzeylerine Ełkisi
}

University of Health Sciences, Ankara Numune Training and Research Hospital, Clinic of Dermatology, Ankara, Turkey

\footnotetext{
Correspondence/ Yazışma Adresi:

Pınar Incel Uysal, University of Health Sciences, Ankara Numune Training and Research Hospital, Clinic of Dermatology, Ankara, Turkey

E-mail: pinarincel@hotmail.com ORCID-ID:

orcid.org/0000-0002-4540-6560 Submitted/Geliş Tarihi: 12.04.2018 Accepted/Kabul Tarihi: 10.06.2018
}

${ }^{\circledR}$ Copyright 2018 by Turkish Society of Dermatology by Galenos Publishing House.

\section{Abstract}

Objective: The aim of this study is to assess the impact of omalizumab on coagulation biomarkers and immunoglobulin E (lgE) levels in chronic idiopathic urticaria/chronic spontaneous urticaria (CIU/CSU) and bullous pemphigoid (BP) patients.

Methods: Medical records of $31 \mathrm{CIU} / \mathrm{CSU}$ and $16 \mathrm{BP}$ patients were reviewed according to the inclusion and exclusion criteria. Laboratory parameters for coagulation status and IgE levels at baseline and in the first 12-week period of omalizumab therapy were retrieved and analysed in the light of clinical response to the treatment.

Results: At baseline, in CIU/CSU patients, IgE levels were significantly higher in responders [184.5 $\mathrm{IU} / \mathrm{mL}(62-307 \mathrm{IU} / \mathrm{mL})]$ than non-responders [25.6 $\mathrm{IU} / \mathrm{mL}$ (10.8-30.2 $\mathrm{IU} /$ $\mathrm{mL})](p=0.021)$. During the first 12 weeks of omalizumab therapy, a dramatic decrease in D-dimer levels was observed in serial measurements of CIU/CSU $(p=0.001)$ and also BP patients ( $p=0.017)$. Total IgE levels were increased after omalizumab usage in all study groups ( $p=0.003$ ) and elevation of IgE levels was found significant for CIU/CSU but not for $B P(p<0.001, p=0.278$, respectively).

Conclusion: Baseline IgE levels may be used to predict which patients will gain benefit from omalizumab therapy in CIU/CSU group. During omalizumab therapy the plasma D-dimer levels show a dramatic decrease in the group of patients who responded of CIU/CSU and BP.

Keywords: Anti-immunoglobulin E therapy, bullous pemphigoid, chronic urticaria, coagulation parameters, immunoglobulin E, omalizumab

\section{Öz}

Amaç: Bu çalışmanın amacı kronik idiyopatik ürtiker/kronik spontan ürtiker (Kiü/KSÜ) ve büllöz pemfigoid (BP) hastalarında omalizumabın koagülasyon biyobelirteçleri ve immünoglobulin E (lgE) seviyeleri üzerine etkisini değerlendirmektir.

Yöntemler: Dahil etme ve dışlama kriterlerine uygun olan 31 KiÜ/KSÜ ve 16 BP hastasının tıbbi kayıtları gözden geçirilmiştir. Tedavi başlanmasından hemen önce ve omalizumab tedavisinin ilk 12 haftalık periyoduna ait koagülasyon durumuna ilişkin laboratuvar parametreleri ve IgE seviyelerine ilişkin veriler alınarak tedaviye klinik cevap doğrultusunda analiz edilmiştir.

Bulgular: Başlangıçta, KiÜ/KSÜ hastalarında, IgE seviyeleri tedaviye cevap veren hastalarda [184,5 $\mathrm{IU} / \mathrm{mL}(62-307 \mathrm{IU} / \mathrm{mL})]$ cevapsızlardan anlamlı biçimde yüksekti [25,6 $\mathrm{IU} / \mathrm{mL}(10,8-30,2 \mathrm{IU} / \mathrm{mL})] \quad(\mathrm{p}=0,021)$. Omalizumab tedavisinin ilk 12 haftası sürecinde KiÜ/KSÜ hastalarında $(p=0,001)$ ve ayrıca BP hastalarında $(p=0,017)$ seri ölçümlerde D-dimer seviyelerinde dramatik düşüş gözlendi. Tüm çalışma grubunda omalizumab kullanımından sonra total IgE seviyelerinde yükselme izlendi $(p=0,003)$ ve IgE yükselmesi KiÜ/KSÜ için anlamlı iken BP için değildi (sırası ile $p<0,001, p=0,278$ ). 


\section{Öz}

Sonuç: Başlangıç IgE seviyeleri KiÜ/KSÜ grubunda hangi hastaların omalizumab tedavisinde fayda göreceğini tahmin etmekte kullanılabilir. Omalizumab tedavisi sürecinde plazma D-dimer seviyeleri KiÜ/KSÜ ve BP tedaviye cevap veren hastalar grubunda dramatik düşme göstermektedir.

Anahtar kelimeler: Anti-immünoglobulin E tedavi, büllöz pemfigoid, kronik ürtiker, koagülasyon parametreleri, immünoglobulin E, omalizumab

\section{Introduction}

The interaction between immune reaction, inflammatory response and coagulation is evident $(1,2)$. Coagulation system has been extensively investigated in chronic idiopathic urticaria/chronic spontaneous urticaria (CIU/CSU) patients. Activation of coagulation cascade; both of extrinsic and intrinsic pathways, has been shown in these specific studies (3-5). In patients with severe CIU/CSU, the activation of coagulation pathway seem to be in parallel with disease activity $(6,7)$. In particular, D-dimer levels have been regarded as a predictive marker of severity of acute and chronic urticaria (7). In addition, recently, possible involvement of blood coagulation system in the pathogenesis of bullous pemphigoid (BP) has been demonstrated (8-10). Generation of thrombin has been associated with tissue damage and blister formation since in blister fluid samples, D-dimer concentrations and prothrombotic markers $\mathrm{F} 1+\mathrm{F} 2$ were increased (8). In vitro studies have shown that thrombin induces mast cell degranulation and markers of thrombin formation are present even if there is no clinical "thrombosis" (11). Indeed, the risk of thrombosis is increased in BP patients (12). It has been suggested that, reduction of the coagulation activation in clinical remission period of BP patients may also reduce overall thrombotic risk $(8,13)$.

Omalizumab, which is a human monoclonal antiimmunoglobulin E (IgE) antibody has been shown to be effective in patients with CIU/CSU refractory to antihistamines in numerous clinical studies (14-17). Omalizumab diminishes the expression of IgE receptor on immune cells and prevents the binding of $\lg E$ to its receptor. As a result, the effect of IgE on mast cells and basophiles are neutralized $(18,19)$. It has been exclusively approved for use in severe allergic asthma and CIU/CSU. However, recently, in the field of dermatology, the use of omalizumab has expanded beyond the realm of CIU/CSU (20). The evidence demonstrating elevated levels of circulating IgE in majority of BP patients and IgE antibodies specifically targeting BP180 autoantigen (non-collagenous 16 A domain) have lead to therapeutic trials of omalizumab in BP patients with promising results (21-26).

Omalizumab is an effective treatment option for CIU/ CSU and promising treatment option for BP, however all mechanisms of action still remain unclear. More recently, besides known mechanism of action of omalizumab in CIU/CSU, studies have focused on potential mechanisms of action including decreasing coagulation system involvement that contribute to efficacy of omalizumab (27). Furthermore, in a subset of patients, decrease in plasma D-dimer levels in accordance with clinical response to omalizumab therapy in CIU/CSU patients was identified (28). On the other hand, baseline IgE levels were suggested to be predictive for the outcomes of omalizumab treatment in CSI/CIU patients (29). However there is still paucity of data regarding exact predictive factors and markers to determine whether or not the remission can occur. To date no data are available concerning both conditions; CIU/CSU and BP. With this background, we aimed to evaluate the impact of omalizumab usage on coagulation biomarkers and total IgE levels in patients with CIU/CSU and BP. In addition, we examined the link between changes in the laboratory measurements over 12 weeks period and overall response of CIU/CSU and BP patients to omalizumab therapy.

\section{Methods}

\section{Study Design}

We conducted a retrospective self-control study. Medical records of patients with the diagnosis of CIU/CSU or BP who had received at least 12 weeks treatment of omalizumab injections in our dermatology department from December 2014 to December 2017 were reviewed. The study was performed to directly evaluate the impact of omalizumab use on coagulation parameters in patients with the diagnosis of CIU/CSU and BP. The study protocol was approved by the Local Ethics Committee of University of Health Sciences, Ankara Numune Training and Research Hospital with the number of E-17-1599 on 8 November 2017.

\section{Patients}

Forty-seven subjects (mean age 56 years, range 21-93 years, male/female 12/35) treated with omalizumab between the period December 2015 and December 2017 were included in the study. Subjects consisted of $31 \mathrm{CIU} / \mathrm{CSU}$ patients and 16 BP patients. The diagnosis of CIU/CSU was established as having episodes of hives and/or angioedema for a period of longer than 6 weeks. The diagnosis of CIU/CSU was made based on typical clinical characteristics. CIU/CSU patients who had not been treated with systemic corticosteroids for at least 1 week were included. BP diagnosis was based on the clinical, histopathological and immunological characteristics of the patients. All patients exhibited the generalized, classical type BP lesions. Microscopic examination of the skin samples revealed subepidermal bullae and perilesional skin exhibited linear IgG and/or C3 in the basement membrane zone (BMZ) in all patients. Circulating anti-BMZ autoantibodies and antiBP180 antibodies were available in 10/16 cases.

Fixed dose of omalizumab was started for all patients because of lack nomograms predicting optimal dosing for CIU/CSU and BP patients. Omalizumab injections (300 mg 
subcutaneously in 47 patients) was administered either $2(10 / 47)$ or 4-week (37/47) intervals. Final treatment intervals were ranging from 2 weeks to 8 weeks. Patients who had received required tests before each omalizumab administration during first 12 weeks of treatment period were initially selected. Required tests were as follows; total IgE levels and coagulation tests, D-dimer, fibrinogen (FIB). Coagulation tests were prothrombin time (PT), activated partial thromboplastin time (APTT), international normalized ratio (INR). Also baseline platelet (PLT) levels were included. All results were analysed in terms of the clinical response to omalizumab.

Response to therapy was identified based on the review of medical charts and grouped as complete (relief of symptoms and total improvement of lesions), partial (any subjective or objective recovery) or none for CIU/CSU patients. Complete control of BP was determined in patients without active lesions or new lesion development. Based on the medical records complete and partial responders of CIU/CSU and BP patients who have achieved complete control of disease were independently grouped as follows: responders and nonresponders. Therapy response patterns to omalizumab in CIU/CSU and BP groups were recorded. Patients with clinical response before week 4 and after week 12 were grouped as early and late responders.

Demographical data (age, sex), medical history, smoking status, treatment interval, total number of omalizumab administration and the number of omalizumab administration which the clinical response has achieved of all patients were recorded. Patients with missing data were excluded. Patients with concomitant neoplastic diseases, severe systemic and infectious disease were not included. Data of patients with medical history of asthma, allergic rhinitis and atopic dermatitis were not included. Patients who have used drugs affecting coagulation system such as anticoagulants and antiaggregants prior to admission were excluded.

\section{Laboratory Analysis}

Our department has standardized clinical and laboratory analyses for CIU/CSU and BP patients underwent omalizumab therapy such as blood routine test, coagulation parameters, D-dimer, FIB tests and total IgE levels. Results of baseline PLT, D-dimer and coagulation tests, FIB and lgE levels were recorded. Also during treatment repeated (in every 2 or 4 weeks) measurements (PT; INR; APTT; D-dimer, FIB) before omalizumab administration were retrieved form medical records. Total IgE at week 12 of omalizumab treatment was examined. The normal ranges of the laboratory parameters accepted in this study were as follows: PT: 11-15 s, APTT: 24-36 s, INR: 0.8-1.2, FIB: 200-400 mg/dL, D-dimer: 0-0.5 $\mu \mathrm{g} / \mathrm{mL}$, PLT:

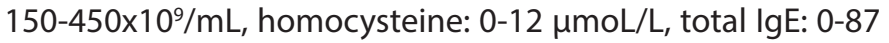
$\mathrm{IU} / \mathrm{mL}$. A value of above each upper limit was categorized as "elevated".

\section{Statistical Analysis}

Statistical analyses were carried out using SPSS software (version 21.0 for Windows; SPSS Inc., Chicago, IL, USA). Parametric variables were presented as means and standart deviations and non-parametric variables were presented as medians and interquartile ranges (IQR). For categorical variables number of cases and percentages were used. Chi-square or Fisher's exact test were used for analyzing categorical variables. Kolmogorov-Smirnov and histogram analyses were used to determine whether continous variables were normally distributed. Normally distributed numeric variables were analysed using Student's t-test and ANOVA. Mann-Whitney $U$ and Kruskal-Wallis tests were used for comparing non-normally distributed numeric variables. Correlations of numeric variables were assessed by Spearman and Pearson tests. Receiver operating characteristic (ROC) curves were used for testing predictive values of baseline laboratory parameters for the response of omalizumab treatment. The area under the curve was calculated for assesing response pattern and sensitivity and specifity were presented if significant cut-off value was detected. The level of significance was set as $\mathrm{p}<0.05$.

\section{Results}

\section{Patient Characteristics and Omalizumab Response Patterns}

The medical records of 65 patients were reviewed. Among these, 18 patients were excluded because of their medical history (asthma, coronary heart disease or cerebrovascular disease) or medications they were taking. Remaining 47 patients with female predominance (35 females, 12 males) were included in the study.

Demographical, clinical and treatment characteristics of CIU/ CSU and BP patients are summarized in Table 1.

Overall response rates to omalizumab treatment were similar among $\mathrm{CSI} / \mathrm{CIU}$ and $\mathrm{BP}$ groups with the ratio of $87 \%$ and $73 \%$, respectively $(p=0.07)(65 \%$ complete, $22 \%$ partial response in CIU/CSU group vs). In CIU/CSU group $15(48 \%)$ patients responded within the first week of the therapy. Median value of total number of omalizumab administration was higher in BP group than CIU/CSU group ( 8 versus $6, p=0.07$ ). Statistically significant difference were observed in the median omalizumab dose to induce remission between CIU/CSU and BP groups $(p<0.001)$. No differences were observed between male and female subjects in response patterns and required median number of omalizumab administration up to remission $(p=0.40)$. Also there was no correlation between response status and clinical characteristics including age, smoking status, presence of angioedema and disease duration.

\section{Comparisons of Baseline Platelet Counts, Coagulation, D-dimer Tests Between Responders and Non-responders}

Median values IQR of PT, INR, APTT; D-dimer, FIB and total IgE levels at baseline are shown in Table 2.

The baseline median PLT counts (IQR) was 268x109/L (227.75335) for all study group. There were not statistically significant differences in median PLT counts between CIU/CSU and BP patients $(p=0.55)$. Baseline median PLT counts were similar in responders and non-responders $(p=0.55)$. Also, baseline 
coagulation parameters (PT; INR; APTT) were not associated with lack of therapy response ( $p>0.05)$. D-dimer levels were elevated in $82 \%$ ( $75 \%$ of CIU/CSU patients, $93 \%$ of BP patients) of all subjects [71.5 $\mu \mathrm{g} / \mathrm{dL}$ (IQR: 1.32-307)]. Before first omalizumab injection $D$-dimer levels quietly different among CIU/CSU [31 $\mu \mathrm{g} / \mathrm{dL}$ (IQR: 0.40-93.25)] and BP patients [324 $\mu \mathrm{g} / \mathrm{dL}$ (IQR: 196.25-967)] ( $p<0.001)$. In both groups (CIU/CSU and BP) baseline D-dimer levels were similar among different response patterns (CIU/CSU; $p=0.31, B P ; p=0.95)$. Twelve of 47 patients had elevated FIB levels $332.5 \mathrm{mg} / \mathrm{dL}$ (IQR: 295402.75). Median values of FIB were similar in CIU/CSU patients and BP patients before omalizumab therapy $(p=0.14)$. However, baseline FIB levels were lower in responders 329 $\mathrm{mg} / \mathrm{dL}$ (IQR: 286.75-392) than in non-responders $403 \mathrm{mg} / \mathrm{dL}$ (IQR: 328.5-439.5) ( $p=0.034)$. Separate analyses for CIU/CSU and BP patients did not show statistical significance.

\section{Comparison of Baseline Total Immunoglobulin E Levels Between Responders and Non-responders}

Serum levels of baseline total IgE were elevated in $67.4 \%$ [322 $\mathrm{IU} / \mathrm{mL}$ (62-336)] of patients ( $58 \%$ of CIU/CSU, $87 \%$ of BP). There was no difference in baseline lgE levels between responders and non-responders in BP group ( $p=0.77)$. However, in CIU/ CSU patients baseline lgE levels were remarkably higher in responders $[184.5 \mathrm{IU} / \mathrm{mL}(62-307)]$ than in non-responders [25.6 IU/mL (10.8-30.2)] $(p=0.021)$. As it was determined by ROC analyses, baseline lgE level predict response with cut-off value of $31.35 \mathrm{IU} / \mathrm{mL}$ (specifity $100 \%$, sensitivity $85.2 \%$ ) (Figure 1). There was not statistical significance between timing of omalizumab responses (between early and late responders) and baseline IgE levels in CIU/CSU patient. Median IgE levels of early, late and non-responders were 133 (IQR: 51.9-248), 123 (IQR: 31.4-256.5), $25.6(10.8-30.2)$ respectively ( $\mathrm{p}=0.063)$.

Comparative analyses of laboratory parameters at baseline and week 12 are shown in Table 2 .

This self control study showed that omalizumab injections had significant effects on PT, INR, APTT and D-dimer tests but not for FIB (Table 2).

PT tests showed significant increase in CIU/CSU patients over 12 weeks time period ( $p=0.013$ ). Sixty-seven percent of patients had increment during omalizumab therapy. Median difference in PT test was $1.4 \mathrm{~s}$ (IQR: 0.6-3.9). During omalizumab therapy INR values decreased $(p=0.006)$.

Table 1. Demographical and clinical characteristics of patients with chronic idiopathic urticaria/chronic spontaneous urticaria and bullous pemphigoid undergoing omalizumab treatment

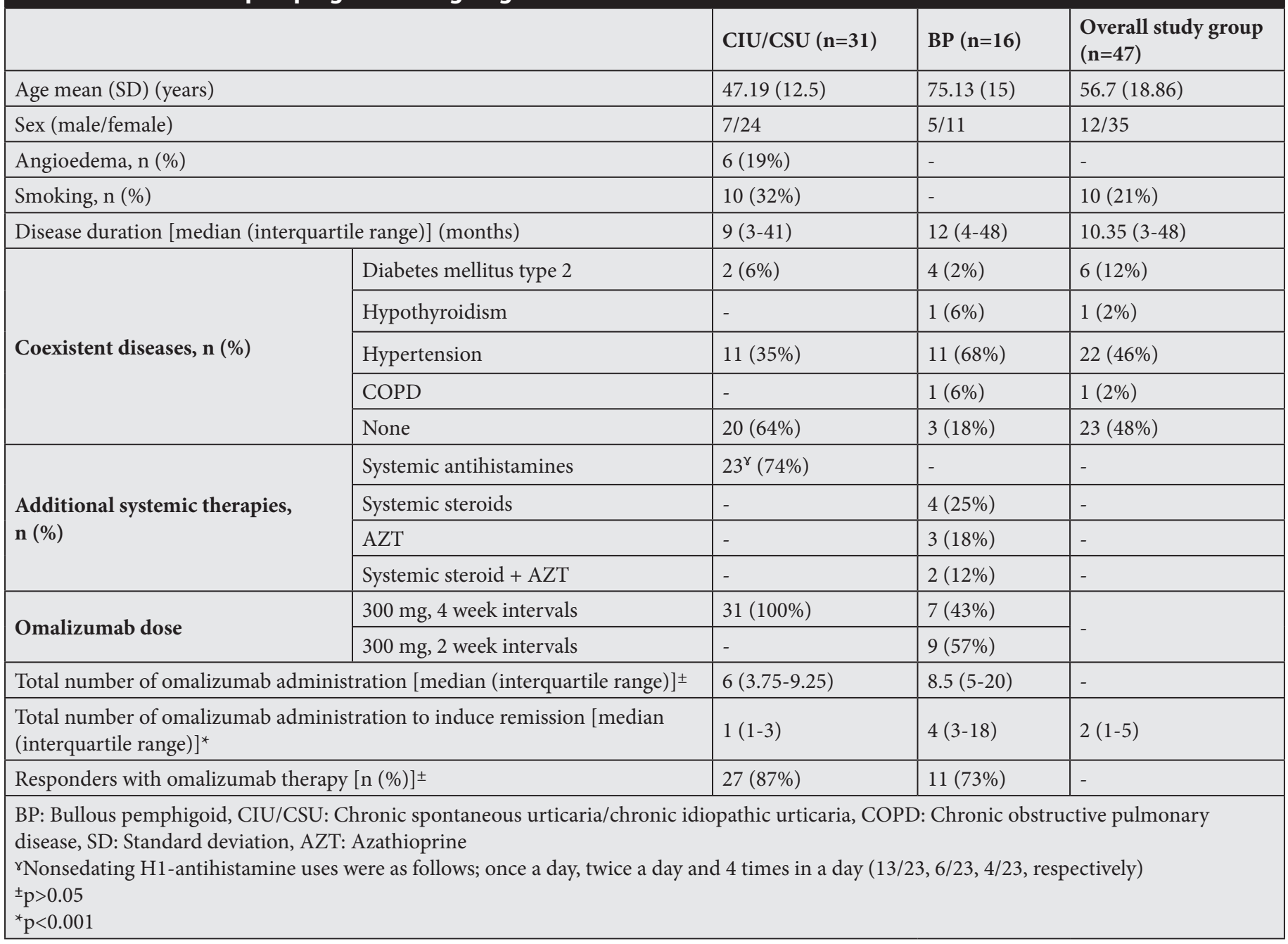


Median INR change was 0.07 s (IQR: 0.03-0.11). This decrement was particularly significant in CIU/CSU patients $(p=0.02)$. Also, the difference was significantly correlated



Figure 1. In chronic idiopathic urticaria/chronic spontaneous urticaria baseline immunoglobulin E levels predict the clinical response of patients

AUC: Area under the curve, ROC: Receiver operating characteristic, IgE: Immunoglobulin $E$ with the time of measurement $(r=0.45, p=0.001)$. APTT results were different with the median value of difference 2 s (IQR: 0.8-2.7) in CIU/CSU patients. This decrement was not observed in BP group. We could not detect any difference in FIB levels before and after omalizumab therapy.

The impact of omalizumab therapy on D-dimer levels was examined. Decrease of levels of blood D-dimer was obvious in $82.6 \%$ of the total study population after the first injection of the drug (Figure 2). Ratio of the patients who had D-dimer level decrease was similar in both patient groups $(87.6 \%$ in CIU/CSU vs $75 \%$ in BP patients, $p=0.32$ ). In serial measurements of plasma D-dimer levels, there was remarkable decrease in each group during 12 weeks treatment period (CIU/CSU; $p=0.001, B P ; p=0.017$ ). D-dimer plasma levels showed a dramatic decrease after the first dose of omalizumab in all responders $(p=0.003)$ however the decresase was not significant among non-responders $(p=0.068)$.

Changes in levels of total IgE before and after omalizumab treatment: after 12 weeks of omalizumab treatment $82.6 \%$ [462 IU/mL (IQR: 137-606)] of the patients had elevated IgE. Overall study group had significant increase in total IgE levels in the first 12 weeks of treatment $(p<0.001)$. This increment was significant in CIU/CSU patients $(p<0.001)$ whereas not in BP patients $(p=0.278)$ (Table 2) (Figure 3$)$. Among responders ratio of the patients who had increase in total IgE levels after $12^{\text {th }}$ week of omalizumab treatment was remarkably higher than non-responders ( $71.1 \%$ vs $50 \%$ respectively). This difference did not reach statistical significance. There was not any correlation between rate of $\mathrm{IgE}$ increase and response dose and timing.

Table 2. Comparisons of the tests at baseline and after 12-week treatment period

\begin{tabular}{|c|c|c|c|c|c|c|c|c|c|}
\hline & \multicolumn{2}{|c|}{$\mathrm{CIU} / \mathrm{CSU}$} & \multirow{2}{*}{ p } & \multicolumn{2}{|c|}{ BP } & \multirow{2}{*}{$\mathbf{p}$} & \multicolumn{2}{|c|}{ Total group } & \multirow{2}{*}{$\mathbf{p}$} \\
\hline & Before & After & & Before & After & & Before & After & \\
\hline $\begin{array}{l}\text { PT [median } \\
\text { (interquartile } \\
\text { range)] }\end{array}$ & $\begin{array}{l}12.2 \\
(11.65-12.9)\end{array}$ & $\begin{array}{l}12.7 \\
(11.97-13.12)\end{array}$ & 0.025 & $\begin{array}{l}12 \\
(11.1-13.12)\end{array}$ & $\begin{array}{l}12.2 \\
(11.8-13.45)\end{array}$ & 0.64 & $\begin{array}{l}12.15 \\
(11.5-12.9)\end{array}$ & $\begin{array}{l}12.6 \\
(11.9-13.1)\end{array}$ & 0.035 \\
\hline $\begin{array}{l}\text { INR [median } \\
\text { (interquartile } \\
\text { range)] }\end{array}$ & $\begin{array}{l}0.99 \\
(0.91-1.1)\end{array}$ & $\begin{array}{l}0.98 \\
(0.90-1.04)\end{array}$ & 0.017 & $\begin{array}{l}1.05 \\
(0.99-1.18)\end{array}$ & $\begin{array}{l}1 \\
(0.92-1.07)\end{array}$ & 0.009 & $\begin{array}{l}1.005 \\
(0.93-1.13)\end{array}$ & $\begin{array}{l}0.98 \\
(0.91-1.05)\end{array}$ & 0.001 \\
\hline $\begin{array}{l}\text { APTT [median } \\
\text { (interquartile } \\
\text { range)] }\end{array}$ & $\begin{array}{l}29.9 \\
(28.1-32.1)\end{array}$ & $\begin{array}{l}28.8 \\
(27.6-30.45)\end{array}$ & 0.057 & $\begin{array}{l}25.4 \\
(23.4-31.27)\end{array}$ & $\begin{array}{l}27.1 \\
(25.9-29.1)\end{array}$ & 0.89 & $\begin{array}{l}28.6 \\
(27-29.85)\end{array}$ & $\begin{array}{l}28.3 \\
(26.2-31.85)\end{array}$ & 0.19 \\
\hline $\begin{array}{l}\text { Fibrinogen } \\
\text { [median } \\
\text { (interquartile } \\
\text { range)] }\end{array}$ & $\begin{array}{l}329 \\
(293.25-390.5)\end{array}$ & $\begin{array}{l}332 \\
(292-368)\end{array}$ & 0.82 & $\begin{array}{l}388 \\
(296-438.5)\end{array}$ & $\begin{array}{l}339 \\
(312.25-446.25)\end{array}$ & 0.88 & $\begin{array}{l}332.5 \\
(295-402.75)\end{array}$ & $\begin{array}{l}332.5 \\
(302-383)\end{array}$ & 0.91 \\
\hline $\begin{array}{l}\text { Total IgE [median } \\
\text { (interquartile } \\
\text { range)] }\end{array}$ & $\begin{array}{l}116.5 \\
(31.9-248)\end{array}$ & $\begin{array}{l}274 \\
(145-582.75)\end{array}$ & $<0.001$ & $\begin{array}{l}334.5 \\
(170.75-1126)\end{array}$ & $\begin{array}{l}406 \\
(128-1424.25)\end{array}$ & 0.278 & $\begin{array}{l}322 \\
(62-336)\end{array}$ & $\begin{array}{l}462 \\
(137-606)\end{array}$ & 0.003 \\
\hline
\end{tabular}

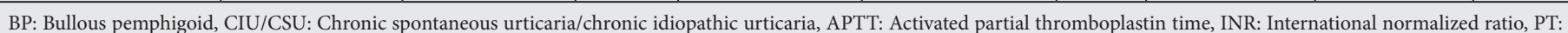
Prothrombin time, IgE: Immunoglobulin E 


\section{Discussion}

Activation of coagulation cascade is able to enhance local inflammation such as skin edema, tissue damage and blister formation and systemic effects including thrombosis $(30,31)$. On the other hand inflammation leads to activation of coagulation. This two way interaction

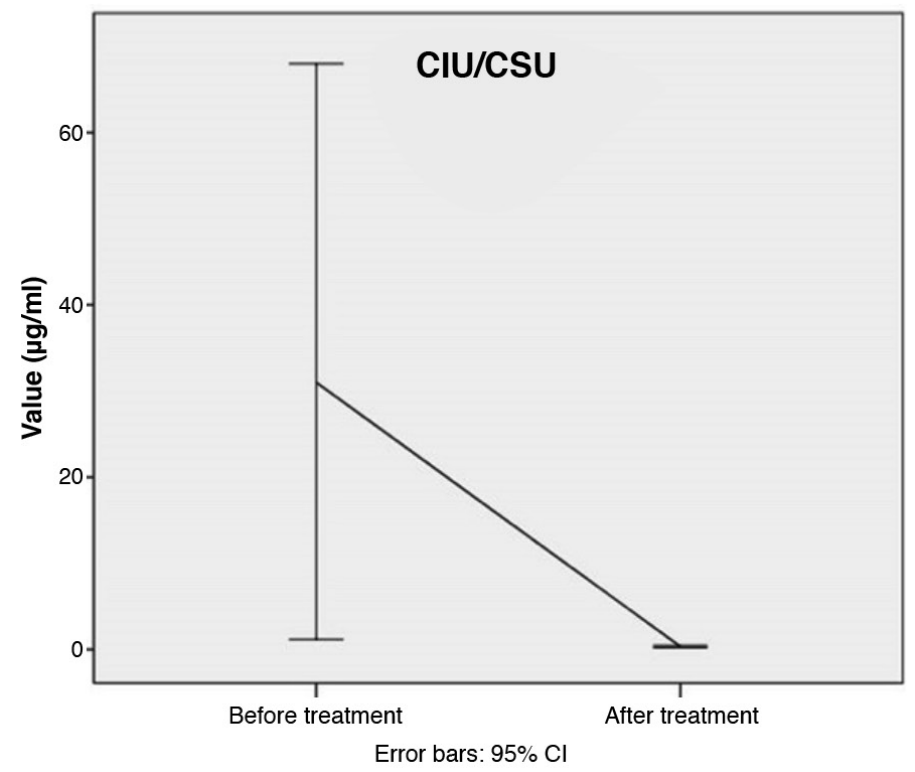

has been regarded to be involved in the pathogenesis of several skin disease $(32,33)$. Furthermore, this interaction is considered to be common intermediate pathogenic step involved in chronic urticaria and BP $(8,10)$. Growing evidence suggests that omalizumab is an effective and safe treatment option for CIU/CSU $(4,24,34)$. Also it has been infrequently used in the treatment of another disease with

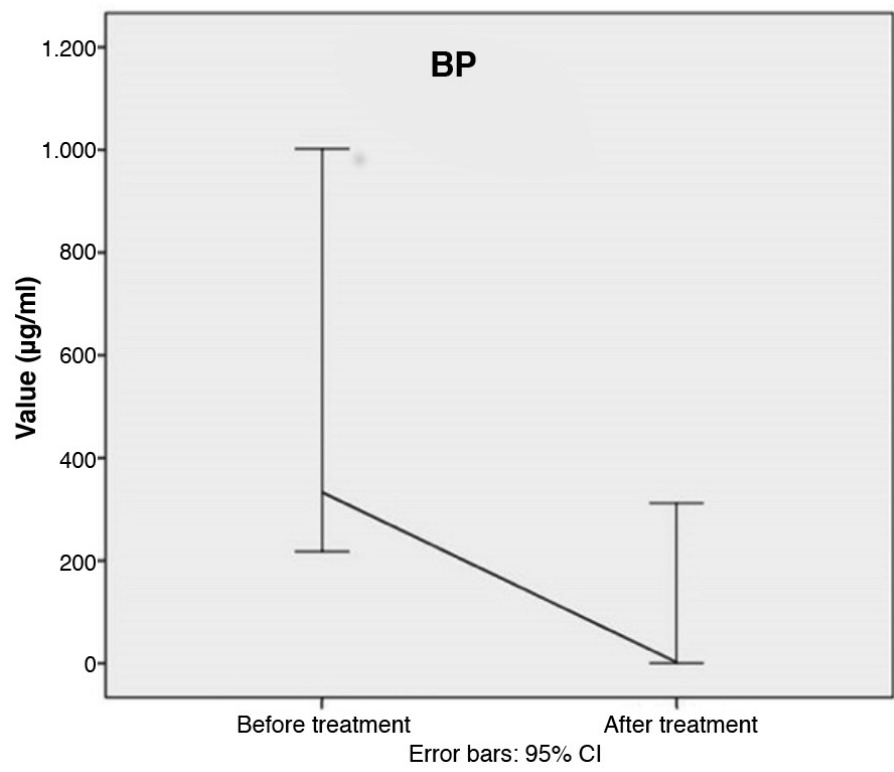

Figure 2. Influence of omalizumab therapy on D-dimer levels in chronic idiopathic urticaria/chronic spontaneous urticaria and bullous pemphigoid patients

BP: Bullous pemphigoid, Cl: Confidence interval, CIU/CSU: Chronic idiopathic urticaria/chronic spontaneous urticaria
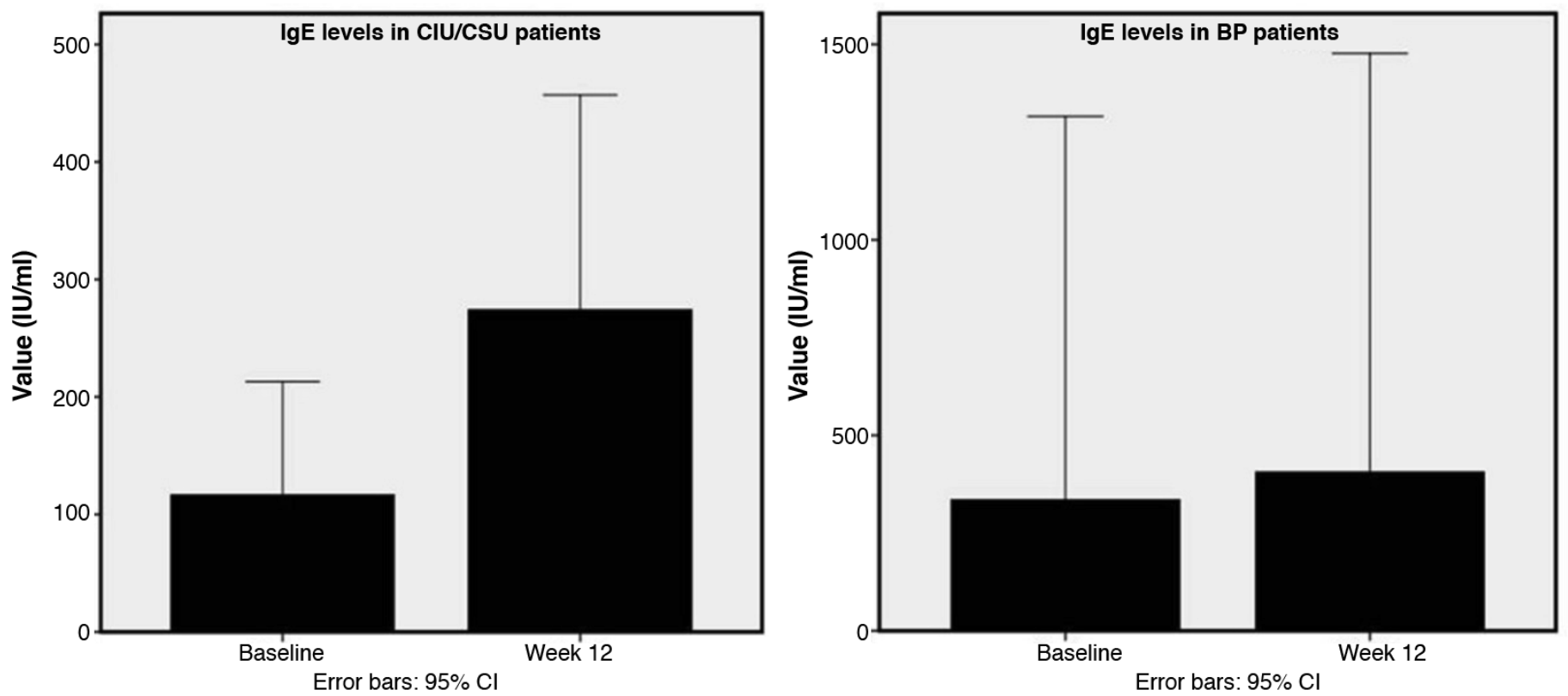

Figure 3. Changes in immunoglobulin E levels in bullous pemphigoid and chronic idiopathic urticaria/chronic spontaneous urticaria patients before and after omalizumab therapy 
activated coagulation system; BP; with generally good results $(12,35,36)$.

Apart from reducing free lgE levels and suppression of FceRI the effect mechanisms of omalizumab still remain unclear. However authors suggest that omalizumab diminishes the role of coagulation activation in pathogenesis of CIU/CSU (27). Recently, it has been shown that omalizumab exerts considerable effects on coagulation system in patients with CSU. In our study, significant differences of coagulation tests with omalizumab usage were detected except FIB. However, each of these changes (PT; INR; APTT) were within normal ranges. Table 2 clearly presents the changing trends of these parameters at 12 weeks of omalizumab treatment compared with before the first administration.

D-dimer appears to be a reliable marker for the severity of chronic urticaria (7). Also, it has been suggested that in BP patients D-dimer levels significantly decrease during remission (13). In addition authors have shown that, after omalizumab administration raised D-dimer levels of CSU patients decrease in paralel with activity of disease (28). Also, it has been suggested that baseline D-dimer levels seem to be predictive for the response of omalizumab (34). Furthermore, early responders had significantly higher D-dimer levels at baseline (34). In accordance with Asero et al. (34), we observed gradually decrease in D-dimer levels of CIU/CSU patients. Importantly, our BP patients had significant reduction in D-dimer levels during 12 week treatment with omalizumab. In terms of this point, omalizumab usage may ameliorate hyperactive coagulation cascade of BP patients which accounts for systemic consequences such as thromboembolism as well as physiopathological effects in skin microenvironment. All responders had very significant $\mathrm{D}$-dimer decrease $(p=0.003)$. Nevertheless, responders and non-responders had similar baseline D-dimer levels. Also we could not detect any correlation between higher baseline D-dimer levels and prompt response in CIU/CSU patients. This was probably because of limited number of refractory patients in each of CIU/CSU and BP group.

Another point in our study was the link between baseline IgE levels and response pattern of patients. More recently, in contrast to the asthma studies, authors have demonstrated that low baseline serum lgE level of CIU/CSU patients is correlated with a lower likelihood of clinical response to omalizumab $(29,35)$. Our study confirms that low IgE $(<31.35$ $\mathrm{IU} / \mathrm{mL}$ ) levels before initiation of omalizumab therapy are associated with poor response to omalizumab. Of note, the difference of early responders, late responders and nonresponders of CIU/CSU group in terms of baseline IgE levels was close to conventional statistical significance $(p=0.06)$ because of presence of limited patients in non-responders and late responders. We believe IgE serum levels before omalizumab therapy may have clinical importance to estimate the time of response. On the other hand, our study shows that low serum levels of IgE are not linked to lack of clinical response of BP patients. Therefore, baseline IgE levels don't seem to be a useful biomarker predicting therapy response for BP patients. During 12 weeks of omalizumab treatment considerable number of patients had elevation lgE levels. This was significant in CIU/CSU, but not in BP. Also lgE increase was more frequent among responders but not predictive for response rate. Altogether, our findings reveal necessity of studies addressing the role of baseline and serial IgE levels in BP patients treated with omalizumab.

\section{Study Limitations}

Our study had several limitations. Main limitations of the study are retrospective study design and the relatively small number of patients. Many patients were excluded, especially in BP group, because of concurrent diseases and medications that they were taking. For today, omalizumab is commonly recommended as corticosteroid sparing agent in treatment of BP. Therefore, some of our BP patients were still on steriod and/or azathioprine therapy. Patients were grouped according their response status based on medical charts. Disease activity scores such as urticaria activity score and Bullous Pemphigoid Disease Activity Index were not able to be included because of retrospective nature of the study. Owing to the high response rate omalizumab in our study population, sample size of non-responder group was too small. Given the retrospective study design other laboratory markers such as fibrin degradation products and F1+F2 could not included.

\section{Conclusion}

In fact, currently, it is not possible to predict in which patients omalizumab could be beneficial. Measurement of baseline serum lgE levels is easy, inexpensive, widely available technique which seem to be utilized as a predictive biomarker for CIU/CSU patients but not for BP patients at present. It has been suggested that omalizumab has similar effects as heparin on extrinsic pathway and D-dimer levels (36). To our knowledge our study represents influence of omalizumab therapy on coagulation parameters and lgE levels in a group of chronic urticaria and BP patients for the first time. Most striking finding of our study is impressive decrease of D-dimer levels of BP patients after the first omalizumab injection in parallel with remission of the disease, as well as CIU/CSU patients. Treatment of BP with omalizumab is still in its infancy. Owing to the increased risk of thrombotic events in these patients, it would be considerable to address anticoagulant effects of omalizumab in the treatment of BP. In conclusion, we believe this study will lead future large studies to investigate useful clinical and biological markers whether a patient is a good candidate for omalizumab, or not.

\section{Ethics}

Ethics Committee Approval: This study protocol was approved by the Local Ethics Committee of University of Health Sciences, Ankara Numune Training and Research Hospital with the number of E-17-1599 on 8 November 2017.

Informed Consent: Retrospective study.

Peer-review: Externally and internally peer-reviewed. 


\section{Authorship Contributions}

Concept:P.I.U., N.A., B.Y., Design:P.I.U., Y.H., N.A., Data Collection or Processing: P.i.U., Y.H., A.A., Analysis or Interpretation: P.i.U., A.Ö., Y.H., Literature Search: N.A., G.G.A., Writing: P.I.U.

Conflict of Interest: No conflict of interest was declared by the authors.

Financial Disclosure: The authors declared that this study received no financial support.

\section{References}

1. Choi G, Schultz MJ, Levi M, et al. The relationship between inflammation and the coagulation system. Swiss Med Wkly 2006;136:139-44.

2. Levi M, van der Poll T. Inflammation and coagulation. Crit Care Med 2010;38:S26-34

3. Asero R, Tedeschi A, Riboldi P, et al. Plasma of patients with chronic urticaria shows signs of thrombin generation, and its intradermal injection causes wheal-and-flare reactions much more frequently than autologous serum. J Allergy Clin Immunol 2006;117:1113-7.

4. Asero R, Cugno M, Tedeschi A. Activation of blood coagulation in plasma from chronic urticaria patients with negative autologous plasma skin test. J Eur Acad Dermatol Venereol 2011;25:201-5.

5. Asero R, Tedeschi A, Riboldi $P$, et al. Severe chronic urticaria is associated with elevated plasma levels of D-dimer. Allergy 2008;63:176-80.

6. Takahagi S, Mihara S, Iwamoto $\mathrm{K}$, et al. Coagulation/fibrinolysis and inflammation markers are associated with disease activity in patients with chronic urticaria. Allergy 2010;65:649-56.

7. BaekYS, Jeon J, Kim JH, et al. Severity of acute and chronic urticaria correlates with D-dimer level, but not C-reactive protein or total IgE. Clin Exp Dermatol 2014;39:795-800.

8. Marzano AV, Tedeschi A, Fanoni $D$, et al. Activation of blood coagulation in bullous pemphigoid: role of eosinophils, and local and systemic implications. The British journal of dermatology 2009;160:266-72.

9. Marzano AV, Tedeschi A, Spinelli $D$, et al. Coagulation activation in autoimmune bullous diseases. Clin Exp Immunol 2009;158:31-6.

10. Cugno M, Tedeschi A, Borghi A, et al. Activation of Blood Coagulation in Two Prototypic Autoimmune Skin Diseases: A Possible Link with Thrombotic Risk. PloS One 2015;10:e0129456.

11. Razin E, Marx G. Thrombin-induced degranulation of cultured bone marrowderived mast cells. J Immunol 1984;133:3282-5.

12. Yang $\mathrm{YW}$, Chen $\mathrm{YH}$, Xirasagar $\mathrm{S}$, et al. Increased risk of stroke in patients with bullous pemphigoid: a population-based follow-up study. Stroke 2011;42:319-23.

13. Marzano AV, Tedeschi A, Polloni I, et al. Prothrombotic state and impaired fibrinolysis in bullous pemphigoid, the most frequent autoimmune blistering disease. Clin Exp Immunol 2013;171:76-81.

14. Kaplan AP, Joseph K, Maykut RJ, et al. Treatment of chronic autoimmune urticaria with omalizumab. J Allergy Clin Immunol 2008;122:569-73.

15. Magerl M, Staubach $P$, Altrichter $S$, et al. Effective treatment of therapyresistant chronic spontaneous urticaria with omalizumab. J Allergy Clin Immunol 2010;126:665-6.

16. Saini S, Rosen KE, Hsieh $\mathrm{HJ}$, et al. A randomized, placebo-controlled, dose-ranging study of single-dose omalizumab in patients with $\mathrm{H} 1$ - antihistamine-refractory chronic idiopathic urticaria. J Allergy Clin Immunol 2011;128:567-73 e1.

17. Maurer M, Rosen $\mathrm{K}, \mathrm{Hsieh} \mathrm{HJ}$, et al. Omalizumab for the treatment of chronic idiopathic or spontaneous urticaria. N Engl J Med 2013;368:924-35.

18. Khan S, Deacock S. Expanding indications of omalizumab therapy in the absence of specific lgE. Allergol Immunopathol (Madr) 2011;39:189.

19. Holgate S, Smith N, Massanari M, et al. Effects of omalizumab on markers of inflammation in patients with allergic asthma. Allergy 2009;64:1728-36.

20. El-Qutob D. Off-Label Uses of Omalizumab. Clin Rev Allergy Immunol 2016;50:84-96.

21. Dimson OG, Giudice GJ, Fu CL, et al. Identification of a potential effector function for IgE autoantibodies in the organ-specific autoimmune disease bullous pemphigoid. The Journal of investigative dermatology 2003;120:784-8.

22. Fairley $\mathrm{JA}$, Burnett $\mathrm{CT}$, Fu CL, et al. A pathogenic role for IgE in autoimmunity: bullous pemphigoid lgE reproduces the early phase of lesion development in human skin grafted to nu/nu mice. The Journal of investigative dermatology 2007;127:2605-11.

23. Messingham KA, Noe MH, Chapman MA, et al. A novel ELISA reveals high frequencies of BP180-specific IgE production in bullous pemphigoid. J Immunol Methods 2009;346:18-25.

24. Yu KK, Crew AB, Messingham KA, et al. Omalizumab therapy for bullous pemphigoid. J Am Acad Dermatol 2014;71:468-74.

25. Balakirski G, Alkhateeb A, Merk HF, et al. Successful treatment of bullous pemphigoid with omalizumab as corticosteroid-sparing agent: report of two cases and review of literature. J Eur Acad Dermatol Venereol 2016;30:1778-82.

26. London VA, Kim GH, Fairley JA, et al. Successful treatment of bullous pemphigoid with omalizumab. Arch Dermatol 2012;148:1241-3.

27. Kaplan AP, Gimenez-Arnau AM, Saini SS. Mechanisms of action that contribute to efficacy of omalizumab in chronic spontaneous urticaria. Allergy 2017;72:519-33.

28. Asero R, Marzano AV, Ferrucci S, et al. D-Dimer Plasma Levels Parallel the Clinical Response to Omalizumab in Patients with Severe Chronic Spontaneous Urticaria. Int Arch Allergy Immunol 2017;172:40-4.

29. Ertas R, Ozyurt K, Atasoy M, et al. The clinical response to omalizumab in chronic spontaneous urticaria patients is linked to and predicted by $\lg \mathrm{E}$ levels and their change. Allergy 2018;73:705-12.

30. Cugno M, Tedeschi A, Asero R, et al. Skin autoimmunity and blood coagulation. Autoimmunity 2010;43:189-94.

31. Tedeschi A, Asero R, Marzano AV, et al. Plasma levels and skin-eosinophilexpression of vascular endothelial growth factor in patients with chronic urticaria. Allergy 2009;64:1616-22.

32. Asero R, Riboldi P, Tedeschi A, et al. Chronic urticaria: a disease at a crossroad between autoimmunity and coagulation. Autoimmun Rev 2007;7:71-6.

33. Asero R, Tedeschi A, Marzano AV, et al. Chronic urticaria: a focus on pathogenesis. F1000Res 2017;6:1095.

34. Asero R, Marzano AV, Ferrucci S, et al. Elevated baseline D-dimer plasma levels are associated with a prompt response to omalizumab in patients with severe CSU. J Allergy Clin Immunol Pract 2017;5:1740-2.

35. Straesser MD, Oliver E, Palacios T, et al. Serum IgE as an immunological marker to predict response to omalizumab treatment in symptomatic chronic urticaria. J Allergy Clin Immunol Pract 2018;6:1386-8.e1.

36. Yalcin AD. An overview of the effects of anti-lgE therapies. Med Sci Monit 2014;20:1691-9. 